\title{
A new genus and two new species of dactylogyrid monogeneans from gills of Neotropical catfishes (Siluriformes: Doradidae and Loricariidae)
}

\author{
Aline Angelina Acosta ${ }^{\mathrm{a}, *}$, Tomáš Scholz ${ }^{\mathrm{b}}$, Isabel Blasco-Costa ${ }^{\mathrm{c}}$, Philippe Vieira Alves ${ }^{\mathrm{b}, \mathrm{d}}$, \\ Reinaldo José da Silva ${ }^{a}$ \\ ${ }^{a}$ São Paulo State University (UNESP), Institute of Biosciences, Department of Parasitology, Rua Professor Doutor Antônio Celso Wagner Zanin, $n^{\circ} 250$, Botucatu, São \\ Paulo CEP 18618-689, Brazil \\ b Institute of Parasitology, Biology Centre of the Czech Academy of Sciences, Branišovská 31, 37005 České Budějovice, Czech Republic \\ c Natural History Museum of Geneva, P.O. Box 6134, CH-1211 Geneva, Switzerland \\ d Programa de Pós-Graduação em Biologia Animal, Universidade Federal Rural do Rio de Janeiro, Rodovia BR 465, Km 7, Seropédica, Rio de Janeiro 23851-970, Brazil
}

A R T I C L E I N F O

\section{Keywords:}

South America

Loricariids

Doradids

Host-associations

Integrative taxonomy

\begin{abstract}
A B S T R A C T
A new genus of dactylogyrid monogeneans (Ancyrocephalinae), Paracosmetocleithrum n. gen., is erected to accommodate $P$. trachydorasi n. sp. from Trachydoras paraguayensis (Siluriformes: Doradidae) in the Upper Paraná River basin, Brazil. The new genus differs from Neotropical dactylogyrids in the presence of a well-developed ornamentation in the middle portion of the ventral bar, and a sclerotized patch on the surface of the dorsal bar with an inconspicuous medial process that possesses two submedial projections arising from the tapered ends of this patch. In addition, Demidospermus rhinelepisi n. sp. is described from Rhinelepis aspera (Siluriformes: Loricariidae). The new species, which is the fifth species of the genus described from loricariids, can be differentiated from congeners by the possession of a sclerotized patch attached to the middle portion of the ventral bar, and by morphology of the accessory piece, which presents broad ends, tapering in the centre, rounded proximal end, distal end folding on both sides with folds extending to approximately $3 / 4$ of the accessory piece length. Molecular data on both new species are also provided and species composition of Demidospermus, recently revealed as polyphyletic by molecular studies including the present one, is discussed.
\end{abstract}

\section{Introduction}

Fishes of the order Siluriformes, known as catfishes, have a worldwide distribution with $>3000$ species recognized as valid [1]. Approximately 1700 species (61\%) are found in America, mainly in the Neotropical region [2,3]. Even though catfishes are highly diverse, abundant and of economic importance as food and ornamental fishes, the knowledge of their helminth parasites is still fragmentary and inadequate $[4,5]$. Neotropical catfishes host a rich fauna of gill parasites, especially monogeneans (Dactylogyridae: Ancyrocephalinae) [6,7]. However, the true diversity of these ectoparasites is still poorly known and very little is known about their interrelations $[4,8]$.

Members of the Doradidae are popularly known as thorny or talking catfishes, have exclusively Neotropical distribution and comprise 93 species allocated in 31 genera [9]. Species of only two dactylogyrid genera, Vancleaveus Kritsky, Thatcher et Boeger, 1986 and Cosmetocleithrum Kritsky, Thatcher et Boeger, 1986, are known to parasitize doradids $[10,11]$. Members of the Loricariidae, known as suckermouth catfishes, are the most species-rich (approximately 900 known species) and widespread group of the Siluriformes, distributed throughout South America, reaching north up to Costa Rica $[1,2,12]$. Species of four dactylogyrid genera have been reported from loricariids in the Neotropical region, namely Demidospermus Suriano, 1983, Heteropriapulus Kritsky, 2007, Trinigyrus Hanek, Molnar et Fernando, 1974, and Unilatus Mizelle et Kritsky, 1967 (see [13] and references therein).

Demidospermus was erected by Suriano [14] to accommodate dactylogyrids found on the gills of Loricariichthys anus (Valenciennes) (Siluriformes: Loricariidae). Suriano [14] considered the presence of encapsulated sperm within the testis to be the main diagnosis feature of the genus. Kritsky and Gutiérrez [15] added other genus-specific characteristics and described additional species. In addition, these authors considered Omothecium Kritsky, Thatcher et Boeger, 1987 and Paramphocleithrum Suriano et Incorvaia, 1995 as junior synonyms of Demidospermus. At present, the genus includes 29 species found on fishes of the families Auchenipteridae, Loricariidae, and Pimelodidae [see [16] and references therein], which is uncommonly broad host specificity compared to other genera of Neotropical gill monogeneans, whose species are usually specific to one fish family $[6,7]$.

\footnotetext{
* Corresponding author.

E-mail address: acosta@ibb.unesp.br (A.A. Acosta).
} 
Table 1

List of monogeneans (Dactylogyridae) included in the phylogenetic analyses.

\begin{tabular}{|c|c|c|c|c|c|}
\hline Parasite species & Host & Host family & Locality & Genbank ID & Reference \\
\hline Actinocleidus recurvatus & Lepomis gibbosus & Centrarchidae & River Danube, Slovak Republic & AJ969951 & {$[42]$} \\
\hline Aphanoblastella aurorae & Goeldiella eques & Heptapteridae & Santa Clara, Peru & KР056239 & [8] \\
\hline Aphanoblastella sp. 3 & Goeldiella eques & Heptapteridae & Nanay River, Peru & KP056238 & [8] \\
\hline Cosmetocleithrum bifurcum & Hassar orestis & Doradidae & Aquarium Momón, Iquitos, Peru & КР056216 & [8] \\
\hline Cosmetocleithrum bulbocirrus & Pterodoras granulosus & Doradidae & Upper Paraná River basin, Brazil & MG001326 & Present study \\
\hline Demidospermus anus & Loricariichthys platymetopon & Loricariidae & Upper Paraná River basin, Brazil & KY766957 & [16] \\
\hline Demidospermus mortenthaleri & Brachyplatystoma juruense & Pimelodidae & Santa Clara, Peru & KP056245 & [8] \\
\hline Demidospermus prolixus & Loricaria prolixa & Loricariidae & Upper Paraná River basin, Brazil & KY766955 & [16] \\
\hline Demidospermus rhinelepisi $\mathrm{n} . \mathrm{sp}$. & Rhinelepis aspera & Loricariidae & Upper Paraná River, basin, Brazil & MG001324 & Present study \\
\hline Demidospermus spirophallus & Loricaria prolixa & Loricariidae & Upper Paraná River, basin, Brazil & KY766954 & [16] \\
\hline Demidospermus sp. 11 & Brachyplatystoma vaillantii & Pimelodidae & Nanay River, Peru & KP056235 & {$[8]$} \\
\hline Demidospermus sp. 23 & Brachyplatystoma vaillantii & Pimelodidae & Nanay River, Peru & КР056236 & [8] \\
\hline Ligictaluridus pricei ${ }^{*}$ & Ameiurus nebulosus & Ictaluridae & River Moldau, Czech Republic & AJ969939 & {$[42]$} \\
\hline Onchocleidus similis ${ }^{*}$ & Lepomis gibbosus & Centrarchidae & River Danube, Slovak Republic & AJ969938 & [42] \\
\hline Paracosmetocleithrum trachydorasi n. gen., n. sp. & Trachydoras paraguayensis & Doradidae & Upper Paraná river basin, Brazil & MG001323 & Present study \\
\hline Dactylogyridae gen. sp. 1 & Hemisorubim platyrhynchos & Pimelodidae & Upper Paraná River basin, Brazil & MG001325 & Present study \\
\hline Dactylogyridae gen. sp. 2 & Hemisorubim platyrhynchos & Pimelodidae & Upper Paraná River basin, Brazil & MG001328 & Present study \\
\hline Dactylogyridae gen. sp. 3 & Sorubim lima & Pimelodidae & Upper Paraná River basin, Brazil & MG001327 & Present study \\
\hline Dactylogyridae gen. sp. 9 & Platynematichthys notatus & Pimelodidae & Santa Clara, Peru & KP056224 & {$[8]$} \\
\hline Dactylogyridae gen. sp. 10 & Platynematichthys notatus & Pimelodidae & Santa Clara, Peru & КР056227 & [8] \\
\hline Dactylogyridae gen. sp. 12 & Sorubim lima & Pimelodidae & Iquitos-Belém, Peru & КР056228 & [8] \\
\hline Dactylogyridae gen. sp. 13 & Hypophtalmus edentatus & Pimelodidae & Nanay River, Peru & КР056230 & [8] \\
\hline Dactylogyridae gen. sp. 18 & Pseudoplatystoma fasciatum & Pimelodidae & Santa Clara, Peru & КР056231 & [8] \\
\hline Dactylogyridae gen. sp. 23 & Platysilurus mucosus & Pimelodidae & Santa Clara, Peru & КР056232 & [8] \\
\hline Dactylogyridae gen. sp. 26 & Platynematichthys notatus & Pimelodidae & Santa Clara, Peru & КР056234 & [8] \\
\hline
\end{tabular}

New sequences obtained for the present study are in bold.

* Sequences used as outgroups.

Molecular phylogenetic analyses of dactylogyrids from Neotropical siluriforms revealed that Demidospermus is polyphyletic, with species from loricariids and pimelodids forming two clades that are not closely related $[8,16]$. The type species of the genus, D. anus Suriano, 1983, forms a monophyletic clade with another two species from loricariids [16]. In the present study, a new species of Demidospermus from a loricariid host, Rhinelepis aspera Spix et Agassiz, in Brazil is described. In addition, a new genus is proposed to accommodate a new species found on the gills of a doradid catfish, Trachydoras paraguayensis (Eigenmann et Ward), and new molecular data on both species are provided. Species composition of Demidospermus and its broad spectrum of fish hosts are briefly discussed.

\section{Material and methods}

\subsection{Sampling}

Fish were captured using gill nets and multifilament cast nets in the Aguapeí River ( $\left.21^{\circ} 3^{\prime} 36.20^{\prime \prime} \mathrm{S}, 51^{\circ} 45^{\prime} 38.58^{\prime \prime} \mathrm{W}\right)$, a tributary of the Paraná River, in the municipality of Castilho, between August 2013 and November 2014. The hosts were collected under the license number 577/2015 IBAMA (Instituto Brasileiro do Meio Ambiente e dos Recursos Naturais Renovávéis). After capture, fish were frozen and later examined in the laboratory. Monogeneans were isolated from the gills, preserved in $70 \%$ ethanol, mounted on slides with Hoyer's medium to study sclerotized structures or stained with Gomori's trichrome to study internal organs [17]. The parasites were studied using V3 Leica Application Suite computerized system for image analysis with differential interference contrast and an Olympus BX51 microscope equipped with phase contrast optics. Illustrations were made with the aid of a drawing tube (camera lucida) mounted on a Leica DMLS microscope equipped with phase contrast optics.

\subsection{Morphological analyses}

Measurements were taken according to Mizelle and Klucka [18] and
Kritsky et al. [19]; they represent the measurement of a straight line between two points expressed in micrometers as the mean followed by range and number of measurements in parentheses. Measurements of haptoral bars of a new species of Demidospermus follow Franceschini et al. [16]. The terminology for the components of the haptor follows Mizelle and Kritsky [20] and Kritsky and Mizelle [21]; hooks are numbered according to Mizelle [22]. Type and voucher specimens are deposited in the Helminthological Collection of the Institute Oswaldo Cruz, Rio de Janeiro, Brazil (CHIOC), the Helminthological Collection of the Instituto de Biociências, Universidade Estadual Paulista, Botucatu, Brazil (CHIBB), and the Helminthological Collection of the Institute of Parasitology, Biology Centre of the Czech Academy of Sciences, České Budějovice (IPCAS).

For comparative purposes, the following type and voucher specimens deposited at CHIOC, CHIBB, and Instituto Nacional de Pesquisas da Amazônia, Manaus, Brazil (INPA) were studied: Demidospermus paranaensis Ferrari-Hoeinghaus, Bellay, Takemoto et Pavanelli, 2010 (4 paratypes - CHIOC 37255); D. spirophallus Franceschini, Zago, Müller, Francisco, Takemoto et Silva, 2017 (6 paratypes - CHIBB 226L-232L); D. prolixus Franceschini, Zago, Müller, Francisco, Takemoto et Silva, 2017 (3 paratypes - CHIBB 233L-236L); D. anus Suriano, 1983 (6 vouchers CHIBB 237L-243L); Cosmetocleithrum gussevi Kritsky, Thatcher et Boeger, 1986 (paratype - INPA PA266-2); C. rarum Kritsky, Thatcher et Boeger, 1986 (holotype - INPA PA270-1); C. striatuli Abdallah, Azevedo et Luque, 2012 (3 vouchers - CHIBB 310-312L), and C. laciniatum Yamada, Yamada, Silva et Anjos, 2017 (4 paratypes CHIBB 306-309L).

\subsection{DNA extraction, amplification, and sequencing}

Specimens of two new species used for molecular analyses, together with three unidentified dactylogyrids morphologically corresponding to Demidospermus from two pimelodid catfishes and Cosmetocleithrum bulbocirrus Kritsky, Thatcher et Boeger, 1986 from Pterodoras granulosus (Valenciennes) (see Table 1), were placed on a slide with a drop of water, covered with a coverslip, identified under the microscope based 
on their morphology and then placed into 96\% molecular-grade ethanol. Conspecific specimens (paragenophores - see [23] for terminology) were fixed with glycerin ammonium picrate (GAP), mounted as permanent preparations with Canada balsam following Ergens [24] and deposited in IPCAS. Genomic DNA was extracted using $200 \mu \mathrm{l}$ of a $5 \%$ suspension of Chelex in deionized water and $2 \mu \mathrm{l}$ of proteinase $\mathrm{K}$, followed by overnight incubation at $56^{\circ} \mathrm{C}$, boiling at $90^{\circ} \mathrm{C}$ for $8 \mathrm{~min}$ and centrifugation at $14,000 \mathrm{rpm}$ for $10 \mathrm{~min}$.

Polymerase chain reactions (PCR) were made in $20 \mu \mathrm{l}$ of the reaction mixture with $3 \mu \mathrm{l}$ of extraction supernatant, $10 \mu \mathrm{l}$ of $2 \times \mathrm{MyFi}^{\mathrm{TM}}$ Mix (Bioline, Taunton, Massachusetts, USA), and $1.6 \mu \mathrm{l}$ of each PCR primer. Partial 28S rDNA (D1-D3 region) was amplified using the primers U178 (5'-GCA CCC GCT GAA YTT AAG-3') and L1642 (5'-CCA GCG CCA TCC ATT TTC A-3') [25]. The thermocycling profile used was: denaturation of DNA $\left(95^{\circ} \mathrm{C}\right.$ for $\left.3 \mathrm{~min}\right)$; 35 cycles of amplification $\left(94^{\circ} \mathrm{C}\right.$ for $30 \mathrm{~s}, 56{ }^{\circ} \mathrm{C}$ for $30 \mathrm{~s}$ and $72{ }^{\circ} \mathrm{C}$ for $1.5 \mathrm{~min}$ ), and $4 \mathrm{~min}$ extension hold at $72{ }^{\circ} \mathrm{C}$. PCR products were run on $1 \%$ agarose gel using gel red and loading buffer. PCR products were purified prior to sequencing using exonuclease I and shrimp alkaline phosphatase enzymes [26]. Amplicons were Sanger sequenced at GATC Biotech (Konstanz, Germany) using the PCR primers and the internal primers 900F (5'-CCGTCTTGAAACACGGACCAAG- $3^{\prime}$ ) [27], 300R (5'- CAACTTTCCCTCACGGTACTTG-3') [25]; L1200R (5'-GCATAGTTCACCATCTTTCGG-3') and ECD2 (5'-CCTTGGTCCGTGTTTCAAGACGGG) [28]. Contiguous sequences were assembled using Geneious version R8 (http://www.geneious. com/; [29]).

\subsection{Alignment and phylogenetic analyses}

Six new sequences of the 28S rDNA fragment were generated (length of 1525-1560 bp) and aligned with 19 published sequences from Genbank of dactylogyrid species belonging to the Ancyrocephalinae (Table 1). Since there are no sequences of any mitochondrial gene for dactylogyrids of Neotropical siluriforms available in GenBank to include into the phylogenetic analyses, this study dealt only with a ribosomal marker. Sequences were aligned using default parameters of MAFFT implemented in Guidance [30] with the extremes of the alignment trimmed. Two datasets of partial 28S rDNA sequences were obtained for phylogenetic analyses: dataset $1-$ all the sequences and nucleotide positions ( $827 \mathrm{bp}$ ); dataset $2-$ a stringent alignment (747 bp) excluding nucleotide positions with alignment score below 0.5 [31].

Phylogenetic analyses were run under Maximum likelihood (ML) and Bayesian inference (BI) criteria, applying the model of nucleotide evolution GTR $+\Gamma+\mathrm{I}$ for the two datasets. The model was selected using jModelTest 2.1.1 [32,33]. ML analyses were carried out using the program RAxML v. 8 [24]. The model parameters and bootstrap support values (1000 repetitions) were estimated using RAxML. BI trees were created using MrBayes v. 3.2 [34] running two independent MCMC runs of four chains for $10^{7}$ generations and sampling tree topologies
A

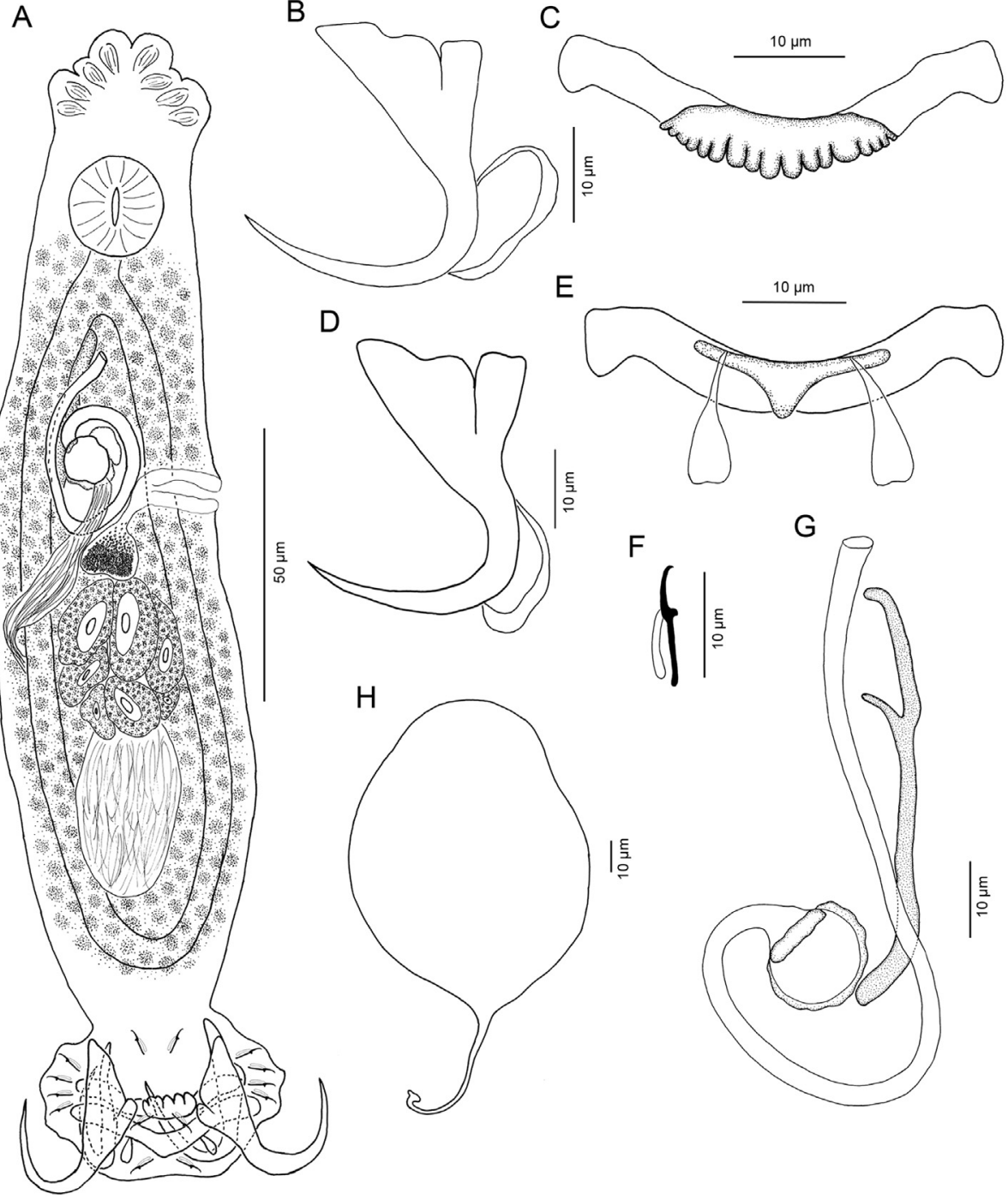

Fig. 1. Paracosmetocleithrum trachydorasi n. gen. and n. sp. from the gills of Trachydoras paraguayensis, Brazil. (A) Whole mount (dorsal view) (holotype - CHIOC 38881a); (B) ventral anchor, (C) ventral bar, (D) dorsal anchor, (E) dorsal bar, (F) hook (paratype - CHIBB 314L); (G) male copulatory complex (ventral view) (paratype - CHIBB 315L); (H) egg (paratype - CHIBB 316L). 
every $10^{3}$ generations. Burn-in periods were set to the first 25,000 generations. MrBayes and RAxML analyses were carried out on the computational resource CIPRES [35]. Genetic divergences were calculated as uncorrected p-distances using MEGA v.6 [36].

\section{Results}

\subsection{Morphological characterization of the new genus}

\subsubsection{Paracosmetocleithrum n. gen. (Fig. 1A-H)}

Diagnosis: Dactylogyridae, Ancyrocephalinae. Body divided into cephalic region, trunk, peduncle, and haptor. Tegument thin, surface smooth. Head organs, cephalic lobes present; cephalic glands unicellular, comprising two bilateral groups, posterolateral to pharynx. Eyes absent. Mouth subterminal, midventral; pharynx muscular, glandular; oesophagus present; intestinal caeca 2, confluent posterior to testis, lacking diverticula. Gonads in tandem, intercaecal; testis posterior to ovary; ovary spherical. Vas deferens looping left intestinal caecum; seminal vesicle a dilation of vas deferens; prostatic reservoir present. Copulatory complex comprising non-articulated copulatory organ and accessory piece; copulatory organ counterclockwise coiled; accessory piece rod-shaped with bifurcated distal end. Common genital pore midventral, at level of intestinal bifurcation. Seminal receptacle at level of anterior margin of ovary; vaginal pore dextral-lateral, nonsclerotized. Vitellarium scattered throughout trunk in form of numerous follicles, except in regions of the reproductive organs. Haptor armed with two pairs of anchors (dorsal and ventral), 14 hooks with ancyrocephalinae distribution [22], ventral and dorsal bars. Ventral bar presents heavily sclerotized ornamentation in its middle portion; dorsal bar presents more sclerotized patch on surface of bar with medial process and with two submedial projections arising from tapered ends of this patch. Parasite of the gills of Neotropical catfishes (Doradidae). Type and only species Paracosmetocleithrum trachydorasi $\mathrm{n}$. sp.

Etymology: The generic name is a combination of the Greek suffix para ( $=$ resembling, similar to) and Cosmetocleithrum because of the morphological resemblance of the new genus with that genus.

\subsubsection{Differential diagnosis}

Paracosmetocleithrum n. gen. differs from all but one Neotropical dactylogyrid genera by the presence of two submedial projections on the dorsal bar (Fig. 1E). The new genus can be distinguished from Cosmetocleithrum, the only genus with two submedial projections on the dorsal bar, by the presence of a well-developed ornamentation in the middle portion of the ventral bar, and a sclerotized patch on the surface of the dorsal bar with an inconspicuous medial process that possesses two submedial projections arising from the tapered ends of this patch. Paracosmetocleithrum n. gen. possesses a dextral vagina, whereas the vagina of all but one species of Cosmetocleithrum is sinistral [17,37]. The only species of Cosmetocleithrum with dextral vagina, C. tortum Mendoza-Franco, Mendoza-Palmero et Scholz, 2016 from the doradid $\mathrm{Ne}$ madoras hemipeltis (Eigenmann) in Peru, differs from the single species of the new genus by the characteristic ornamentation of the ventral bar and a sclerotized patch on the dorsal bar.

\subsubsection{Paracosmetocleithrum trachydorasi n. sp. (Fig. 1A-H)}

Diagnosis based on 12 specimens fixed in Hoyer's medium and 8 stained with Gomori's trichrome: Body fusiform 400 (209-484; 10) long, greatest width $90(44-116 ; 11)$ at mid-length. Cephalic lobes poorly developed; 4 bilateral head organs; eyes absent. Pharynx spherical, 23 (19-26; 5) long, 22 (17-26; 5) wide; oesophagus short; intestinal caeca confluent posterior to testis. Peduncle inconspicuous; haptor subhexagonal, 45 (29-63; 4) long, 56 (44-65; 4) wide (Fig. 1A). Anchors similar in shape, shaft and point evenly curved extending beyond anchor base, base with groove, short superficial and deep roots; ventral anchor 27 (24-29; 12) long, base $18(17-20$; 12) wide (Fig. 1B); dorsal anchor 27 (25-29; 12) long, base $18(16-19 ; 12)$ wide (Fig. 1D).
Ventral bar bowed, broad at ends, with heavily sclerotized ornamentation in its middle portion, 45 (39-49; 11) long (Fig. 1C). Dorsal bar bowed, broad at ends, with more sclerotized patch on surface of bar with medial process, and two submedial projections arising from tapered ends of this patch (Fig. 1E), 47 (41-52; 12) long. Hooks similar, 12 (11-12; 12) long, recurved point, erect thumb, slender shank, FH loop about less than $3 / 4$ of shank length (Fig. $1 F$ ). Male copulatory organ (MCO) slender, forming 1 incomplete counterclockwise ring, broad base, $65(40-76 ; 12)$ long, proximal ring diameter $28(20-34 ; 10)$ (Fig. 1G). Accessory piece $59(52-65 ; 11)$ long, rod shaped with bifurcated distal end (Fig. 1G). Gonads in tandem; ovary pretesticular. Testis $32(n=1)$ long, $18(n=1)$ wide; seminal vesicle dilation of vas deferens; prostatic reservoir present. Vas deferens looping left intestinal caecum. Ovary 41 (39-43; 3) long, $26(23-27 ; 1)$ wide, spherical; oviduct, ootype, and uterus not observed. Seminal receptacle at level of anterior margin of ovary; vagina dextral-lateral, non-sclerotized (Fig. 1A). Vitellarium scattered throughout trunk, except in regions of reproductive organs. Egg oval, with filament opposite to opercular end, 110 (109-110; 2) long, 60 (57-63; 2) wide (Fig. 1H).

\subsubsection{Taxonomic summary}

Type-host: Trachydoras paraguayensis (Eigemann et Ward) (Siluriformes: Doradidae).

Type-locality: Aguapeí River (Paraná River basin), municipality of Castilho, São Paulo State, Brazil ( $21^{\circ} 3^{\prime} 36.20^{\prime \prime}$ S, 51 $\left.{ }^{\circ} 45^{\prime} 38.58^{\prime \prime W}\right)$.

Site on host: Gills.

Infection rate: Prevalence: 70\% (49 fish infected of 70 examined); mean intensity $8 \pm 3$ (1-127).

Specimens deposited: Holotype (CHIOC 38881a); 3 paratypes (CHIOC 38881b-d); 4 paratypes (CHIBB 313-316L), 8 vouchers (CHIBB 317-324L); 4 paratypes (IPCAS M-675); paragenophore (IPCAS M-675).

Representative DNA sequence: 1547 bp long sequence of the D1-D3 region of the lsrDNA of one specimen from $T$. paraguayensis (GenBank Accession No. MG001323).

Etymology: The specific name refers to the generic name of its hosts.

\subsubsection{Remarks}

The new species is the type and single species of the newly erected genus. Therefore, it can be distinguished from species of other dactylogyrid genera by the characteristics listed in the differential diagnosis of the new genus, i.e., the presence of two submedial projections on the dorsal bar, a well-developed ornamentation in the middle portion of the ventral bar, and a sclerotized patch on the surface of the dorsal bar with an inconspicuous medial process with the two submedial projections arising from the tapered ends of this patch (see above).

Analyses of datasets 1 and 2 (see Section 2.4. above) yielded similar topologies and for each of the dataset the BI and ML analyses produced phylogenetic trees with mostly congruent branching topology and support values. Fig. 3 shows the phylogenetic tree obtained using dataset 2 . In a preliminary phylogenetic analysis, $P$. trachydorasi did not cluster with any other sequenced genera of Neotropical siluriforms, including those of clade A in Mendoza-Palmero et al. [8] that comprises dactylogyrids from Neotropical siluriforms and Holartic perciforms. More specific phylogenetic analyses (dataset 1 and 2) revealed $P$. trachydorasi as an independent lineage, sister to the clade composed of Demidospermus spp. and Dactylogyridae gen. spp. from pimelodid catfishes. In turn, this clade is sister to that including two species of Cosmetocleithrum from doradids and 4 species of Demidospermus from loricariids. However, the relationship of the new genus with dactylogyrids from pimelodids remains unresolved due to weak support of this clade (Fig. 3). Paracosmetocleithrum trachydorasi n. sp. appeared genetically distant from all genera of Neotropical dactylogyrids from siluriforms included in this study (Table 2). 
Table 2

Nucleotide divergence (p-distance) among selected dactylogyrids from Neotropical catfishes (747 bp alignment).

\begin{tabular}{|c|c|c|c|c|c|c|c|c|c|c|c|c|c|c|c|c|c|c|c|c|c|c|c|}
\hline & & 1 & 2 & 3 & 4 & 5 & 6 & 7 & 8 & 9 & 10 & 11 & 12 & 13 & 14 & 15 & 16 & 17 & 18 & 19 & 20 & 21 & 22 \\
\hline 1 & $\begin{array}{l}\text { Aphanoblastella sp. } 3 \\
\text { (KP056238) }\end{array}$ & & & & & & & & & & & & & & & & & & & & & & \\
\hline 2 & $\begin{array}{l}\text { Aphanoblastella aurorae } \\
\text { (KP056239) }\end{array}$ & 7 & & & & & & & & & & & & & & & & & & & & & \\
\hline 3 & $\begin{array}{l}\text { Demidospermus prolixus } \\
\text { (KY766955) }\end{array}$ & 25 & 24 & & & & & & & & & & & & & & & & & & & & \\
\hline 4 & $\begin{array}{l}\text { Demidospermus spirophallus } \\
\text { (KY766954) }\end{array}$ & 26 & 28 & 11 & & & & & & & & & & & & & & & & & & & \\
\hline 5 & $\begin{array}{l}\text { Demidospermus anus } \\
\text { (KY766957) }\end{array}$ & 26 & 27 & 7 & 10 & & & & & & & & & & & & & & & & & & \\
\hline 6 & Demidospermus rhinelepisi n. sp. (XXXXX) & 27 & 27 & 10 & 12 & 9 & & & & & & & & & & & & & & & & & \\
\hline 7 & $\begin{array}{l}\text { Cosmetocleithrum bifurcum } \\
\text { (KP056216) }\end{array}$ & 34 & 35 & 26 & 28 & 28 & 26 & & & & & & & & & & & & & & & & \\
\hline 8 & $\begin{array}{l}\text { Cosmetocleithrum bulbocirrus } \\
\text { (XXXXX) }\end{array}$ & 33 & 32 & 22 & 23 & 23 & 23 & 16 & & & & & & & & & & & & & & & \\
\hline 9 & $\begin{array}{l}\text { Paracosmetocleithrum trachydorasi n. gen., n. sp. } \\
(\mathrm{XXXXX)}\end{array}$ & 30 & 30 & 24 & 25 & 25 & 25 & 31 & 29 & & & & & & & & & & & & & & \\
\hline 10 & $\begin{array}{l}\text { Dactylogyridae gen. sp. } 9 \\
\text { (KP056224) }\end{array}$ & 28 & 31 & 22 & 25 & 24 & 24 & 29 & 26 & 26 & & & & & & & & & & & & & \\
\hline 11 & $\begin{array}{l}\text { Dactylogyridae gen. sp. } 26 \\
\text { (KP056234) }\end{array}$ & 29 & 29 & 23 & 24 & 23 & 24 & 29 & 26 & 26 & 7 & & & & & & & & & & & & \\
\hline 12 & $\begin{array}{l}\text { Demidospermus sp. } 23 \\
\text { (KP056236) }\end{array}$ & 27 & 29 & 22 & 24 & 23 & 24 & 28 & 27 & 27 & 13 & 14 & & & & & & & & & & & \\
\hline 13 & $\begin{array}{l}\text { Demidospermus sp. } 11 \\
\text { (KP056235) }\end{array}$ & 28 & 29 & 24 & 25 & 25 & 25 & 30 & 27 & 26 & 14 & 15 & 2 & & & & & & & & & & \\
\hline 14 & $\begin{array}{l}\text { Demidospermus mortenthaleri } \\
\text { (KP056245) }\end{array}$ & 30 & 32 & 21 & 23 & 23 & 23 & 29 & 28 & 27 & 18 & 17 & 17 & 18 & & & & & & & & & \\
\hline 15 & $\begin{array}{l}\text { Dactylogyridae gen. sp. } 23 \\
\text { (KP056232) }\end{array}$ & 30 & 31 & 22 & 23 & 23 & 24 & 30 & 29 & 28 & 17 & 17 & 17 & 18 & 10 & & & & & & & & \\
\hline 16 & $\begin{array}{l}\text { Dactylogyridae gen. sp. } 18 \\
\text { (KP056231) }\end{array}$ & 31 & 31 & 24 & 26 & 26 & 26 & 30 & 29 & 29 & 21 & 19 & 19 & 20 & 15 & 16 & & & & & & & \\
\hline 17 & $\begin{array}{l}\text { Dactylogyridae gen. sp. } 10 \\
\text { (KP056227) }\end{array}$ & 29 & 30 & 23 & 24 & 25 & 26 & 28 & 26 & 26 & 19 & 18 & 17 & 17 & 12 & 14 & 16 & & & & & & \\
\hline 18 & $\begin{array}{l}\text { Dactylogyridae gen. sp. } 13 \\
\text { (KP056230) }\end{array}$ & 31 & 32 & 22 & 24 & 23 & 23 & 30 & 28 & 26 & 18 & 17 & 17 & 18 & 14 & 14 & 16 & 13 & & & & & \\
\hline 19 & $\begin{array}{l}\text { Dactylogyridae gen. sp. } 1 \\
\text { (XXXXX) }\end{array}$ & 31 & 32 & 25 & 27 & 26 & 25 & 29 & 27 & 28 & 20 & 19 & 19 & 20 & 15 & 17 & 18 & 16 & 18 & & & & \\
\hline 20 & $\begin{array}{l}\text { Dactylogyridae gen. sp. } 2 \\
\text { (XXXXX) }\end{array}$ & 31 & 31 & 25 & 27 & 26 & 25 & 30 & 27 & 27 & 21 & 20 & 21 & 22 & 18 & 18 & 20 & 17 & 19 & 6 & & & \\
\hline 21 & $\begin{array}{l}\text { Dactylogyridae gen. sp. } 3 \\
\text { (XXXXX) }\end{array}$ & 29 & 29 & 23 & 25 & 24 & 23 & 29 & 27 & 26 & 17 & 16 & 18 & 19 & 14 & 13 & 15 & 13 & 13 & 13 & 16 & & \\
\hline 22 & $\begin{array}{l}\text { Dactylogyridae gen. sp. } 12 \\
\text { (KP056228) }\end{array}$ & 28 & 29 & 23 & 25 & 24 & 24 & 30 & 28 & 26 & 18 & 17 & 19 & 20 & 14 & 13 & 17 & 14 & 14 & 14 & 17 & 3 & \\
\hline
\end{tabular}

Taxa are listed as they appear in Fig. 3. All values represent percentages.

\subsection{Description of a new Demidospermus species from loricariid}

\subsubsection{Demidospermus rhinelepisi n. sp. (Fig. 2A-I)}

Diagnosis based on 15 specimens fixed in Hoyer's medium and 10 stained with Gomori's trichrome: Body fusiform 559 (394-814; 10) long, greatest width $121(100-136 ; 10)$ at mid-length. Cephalic lobes poorly developed; 4 bilateral head organs; eyes absent. Pharynx spherical, 41 (37-47; 10) long, 39 (36-47; 10) wide; oesophagus short; intestinal caeca confluent posterior to testis. Peduncle broad; haptor subhexagonal, 58 (53-66; 8) long, 75 (69-80; 8) wide (Fig. 2A). Anchors similar in shape, each with poorly developed roots, presenting fissures at base, shaft, and point evenly curved at level of superficial root; ventral anchor 29 (27-32; 15) long, base 20 (18-22; 15) wide (Fig. 2B); dorsal anchor 28 (27-31; 17) long, base 20 (19-22; 15) wide (Fig. 2D). Ventral bar V-shaped, constricted in the middle with sclerotized patch attached to middle portion, rounded ends, with variable aperture of angulation, $66(61-72 ; 15)$ total length, distance between ends 56 (42-64; 15), 19 (12-28; 15) high (Fig. 2C). Dorsal bar Vshaped, articulated in middle with broader two pieces, tapering along its extension, rounded ends, $66(59-74 ; 15)$ total length, distance between ends 55 (40-68; 7), 19 (14-24; 15) height (Fig. 2E). Hooks similar, $14(14-15$; 15) long, recurved point, erect thumb, slender shank, with round, weakly sclerotized subunit at base, FH loop about $3 / 4$ of shank length (Fig. 2F). MCO slender, forming about 11/2 counterclockwise rings, 39 (33-52; 14) long, proximal ring diameter 23 (20-26; 14) (Fig. 2G). Accessory piece 50 (44-53; 15) long, with broad ends and tapering in middle, rounded in proximal end, rounded proximal end, distal end folding on both sides with folds extending to approximately $3 / 4$ of accessory piece length (Fig. 2G). Gonads in tandem; ovary pretesticular. Testis $53(45-61 ; 3)$ long, $33(26-38 ; 1)$ wide; seminal vesicle a dilation of vas deferens, with two conspicuous dilations; prostatic reservoir not observed. Vas deferens looping left intestinal caecum. Ovary 115 (99-129; 4) long, 54 (44-60; 4) wide, spherical; oviduct, ootype, and uterus not observed. Vaginal aperture sinistral-lateral, spherical in shape; vaginal tube sclerotised (Fig. 2I). Vitellarium in form of follicles densely scattered throughout trunk, except around reproductive organs. Egg oval, with filament opposite to opercular end, 87 (1) long, 45 (1) wide (Fig. 2H).

\subsubsection{Taxonomic summary}

Type-host: Rhinelepis aspera Spix et Agassiz, 1829 (Siluriformes: Loricariidae).

Type-locality: Aguapeí River (Paraná River basin), municipality of Castilho, São Paulo State, Brazil ( $21^{\circ} 3^{\prime} 36.20^{\prime \prime}$ S, $\left.51^{\circ} 45^{\prime} 38.58^{\prime \prime} \mathrm{W}\right)$.

Site on host: Gills. 


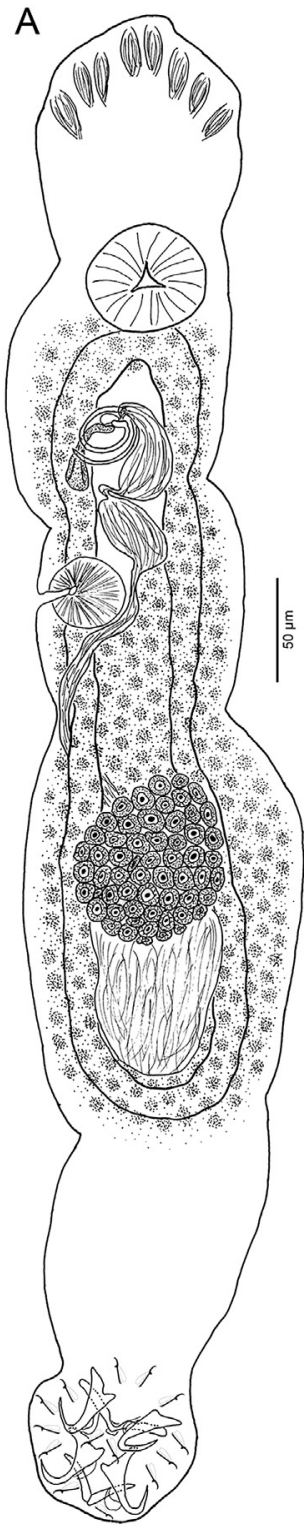

B

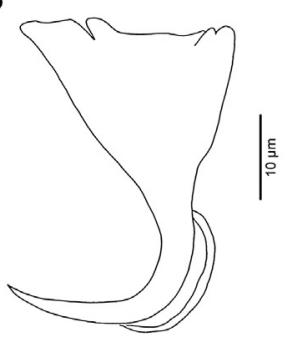

D

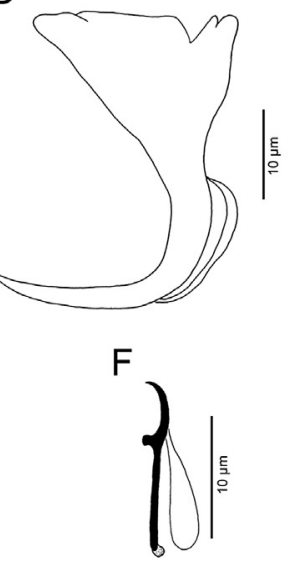

$\mathrm{H}$

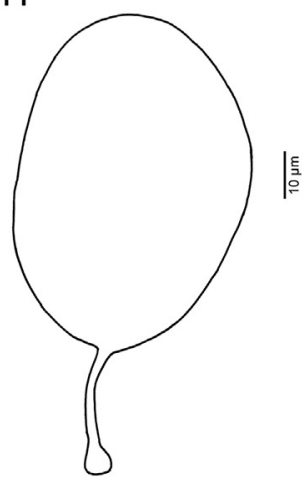

C

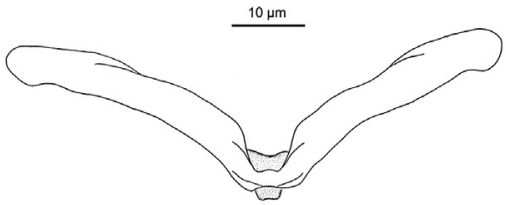

E

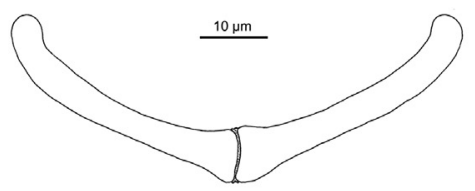

G

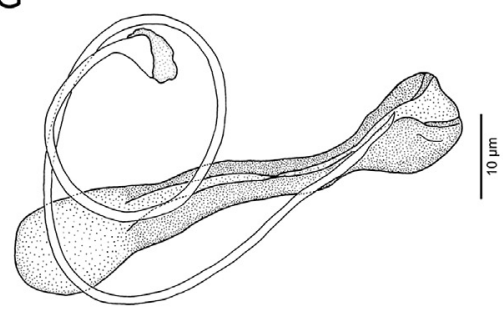

Fig. 2. Demidospermus rhinelepisi $\mathrm{n}$. sp. from the gills of Rhinelepis aspera, Brazil. (A) Whole mount (dorsal view) (holotype - CHIOC 38880a); (B) ventral anchor, (C) ventral bar, (D) dorsal anchor, (E) dorsal bar, (F) hook (paratype CHIBB 325L); (G) male copulatory complex (ventral view) (paratype - CHIBB 326L); (H) egg (paratype - CHIBB 326L); (I) vagina (paratype - CHIBB 327L).
Infection rate: Prevalence: $100 \%$ (30 fish infected of 30 examined); mean intensity $12 \pm 3(1-70)$.

Specimens deposited: Holotype (CHIOC 38880a); 4 paratypes (CHIOC 38880b-e); 4 paratypes (CHIBB 325-328L) 11 vouchers (CHIBB 329-340L); 5 paratypes (IPCAS M-676); paragenophore (IPCAS M-676).

Representative DNA sequence: 1542 bp long sequence of the D1-D3 region of the lsrDNA of one specimen from $R$. aspera (GenBank Accession No. MG001324).

Etymology: The specific name refers to the generic name of its host.

\subsubsection{Remarks}

The new species is considered a member of Demidospermus because of the presence of the characteristics presented in an amended diagnosis of the genus proposed by Kritsky and Gutiérrez [15], i.e., eyes absent, gonads tandem, MCO coiled counterclockwise, accessory piece of MCO sheath-like, vaginal aperture sinistral, and bars V-shaped. Demidospermus rhinelepisi $\mathrm{n}$. sp. differs from its congeners by the possession of a sclerotized patch attached to the middle portion of the ventral bar (Fig. 2C), and by morphology of the accessory piece, which presents broad ends, tapering in the centre, rounded proximal end, distal end folding on both sides with folds extending to approximately $3 / 4$ of the accessory piece length (Fig. 2G).

MCO of D. rhinelepisi n. sp. resembles in shape that of $D$. anus, $D$. paranaensis, $D$. prolixus, and $D$. spirophallus. The new species presents about $1 \frac{1 / 2}{2}$ counterclockwise rings similarly as $D$. prolixus, but it differs in the shape of the accessory piece, which is straight in shape and smaller in $D$. prolixus $(44-53 \mu \mathrm{m}$ in $D$. rhinelepisi $\mathrm{n}$. sp. versus $32-38 \mu \mathrm{m}$ in $D$. prolixus, see Fig. $3 \mathrm{~A}$ in [16]). The MCO of $D$. anus presents $1-1 \frac{1}{2}$ counterclockwise ring, but differs from the new species in the shape (broad distal end and slender proximal end) and smaller size of the accessory piece $(30-33 \mu \mathrm{m})$ in $D$. anus, (see Fig. 4A in [16]). Demidospermus paranaensis presents MCO with 1 counterclockwise ring and differs from $D$. rhinelepisi $\mathrm{n}$. sp. in the shape of the accessory piece, which is rod-like without any folds, with a broader distal end (see fig. $1 \mathrm{G}$ in [39]). Demidospermus spirophallus presents $2^{1 / 2}$ but differs from the new species in the shape of the accessory piece, which is tubular with a bifurcated proximal end (see Fig. 1B in [16]).

Demidospermus rhinelepisi $\mathrm{n}$. sp. is the fifth species of the genus described from loricariid catfishes. Molecular data (partial sequences of $28 \mathrm{~S}$ rDNA) revealed the new species to be sister to $D$. anus, the type species of the genus, within a well-supported clade composed exclusively of species of Demidospermus from loricariids (Fig. 3). 


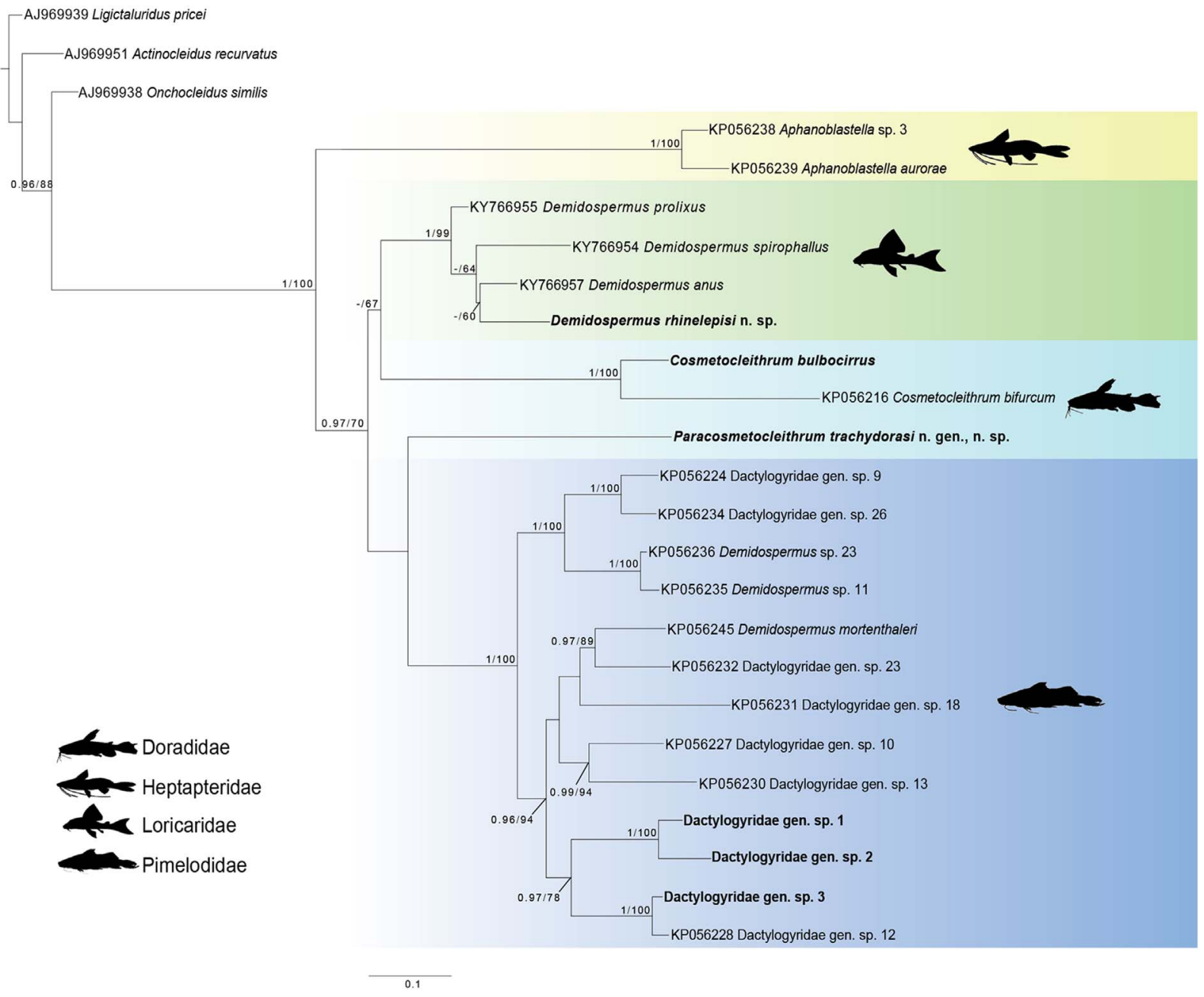

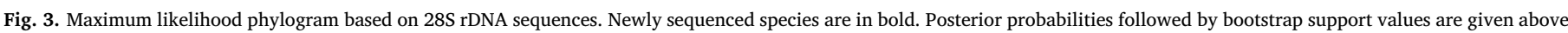

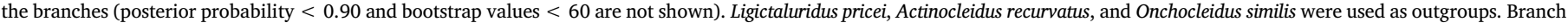
length scale bar indicates number of substitution per site.

\subsection{Phylogenetic relationships among Neotropical dactylogyrids from pimelodids}

Three newly sequenced unidentified species (Dactylogyridae gen. sp. 1, 2, and 3) from pimelodid catfishes [two species from Hemisorubim platyrhynchos (Valenciennes) and one from Sorubim lima (Bloch et Scheneider)] are not closely related to species of Demidospermus from loricariids (Fig. 3), even though their morphology resembles that of species of this genus (data not shown). In contrast, these monogeneans from pimelodids group within a big clade composed of Demidospermus mortenthaleri, two unidentified species of this genus (Demidospermus sp. 11 and sp. 23 of [8]) and 7 dactylogyrids not identified to the genus level (Dactylogyridae gen. sp. 9, 10, 12, 13, 18, 23 and 26 of [8]), all parasitising pimelodid catfishes. The newly sequenced monogeneans form a relatively well-supported clade with another unidentified species, Dactylogyridae gen. sp. 12, which parasitizes the same host, $S$. lima.

\section{Discussion}

In the present study, two new species of dactylogyrid monogeneans were described from Neotropical catfishes. For the new species from a doradid catfish, a new genus is erected because this species possesses unique ornamentation of connecting bars, which is not present in any other dactylogyrid genus $[6,7]$. The second new species is described from a loricariid fish and it is assigned to Demidospermus, one of the species-richest genera of Neotropical monogeneans [16]. Molecular analyses have shown that this genus, which includes species parasitising three different families of siluriform fishes, namely Auchenipteridae, Loricariidae, and Pimelodidae, is not monophyletic $[8,16]$. It is apparent that the species composition of the genus and its delimitation require revision based on this new molecular evidence. The new species of Demidospermus described in the present paper groups with the type species of the genus, $D$. anus, and thus its generic assignment is unquestionable as is its validity considering the morphological and molecular evidence presented herein. Phylogenetic relationships of the new genus to other dactylogyrid genera from Neotropical catfishes remain unresolved due to weak support for the internal nodes of the clade. Nevertheless, nucleotide divergence of its type and only species, Paracosmetocleithrum trachydorasi n. sp., from species of other genera is rather high (see Table 2).

Whereas circumscription of individual species of Neotropical gill monogeneans does not represent a serious problem, delimitation of genera remains problematic in many cases, especially because of the existence of very few synapomorphies that would define unequivocally individual genera. Some genera are defined by unique combination of non-unique characteristics including those of internal structures (e.g. mutual position of genital organs - see [17]). Species composition of some genera such as Urocleidoides Mizelle et Price, 1964 and Demidospermus has changed considerably, depending on the generic concept 
accepted by given authors; these genera include species with a relatively broad spectrum of morphological variability $[4,11]$. Regarding the polyphyly of Demidospermus, the present study provides additional evidence that revision of the species composition and delimitation of this genus is needed. The genus currently includes 29 species from auchenipterids, loricariids and pimelodids [11,16], which is an unusually broad range of definitive hosts for a dactylogyrid genus [40]. A most recent study by Mendoza-Palmero et al. [38] showed that morphologically similar species from same fish hosts may be genetically distant, likely as a result of convergent evolution of morphological traits.

It is possible that the explosive radiation of pimelodid and other catfishes in South America, mostly caused by long and complex history of South American rivers [41], may be reflected in morphological similarity of phylogenetically distantly related dactylogyrids, including species of Demidospermus from different catfish families. This rapid radiation of Neotropical catfishes may not have been accompanied by corresponding phenotypic differentiation.

\section{Conclusion}

Based on morphological and molecular evidence, a new genus of dactylogyrid monogeneans is erected to accommodate a new species from a relatively poorly known group of Neotropical catfishes. In addition, new genetic and morphological data are provided on another new species of Demidospermus, a polyphyletic genus of Neotropical gill monogeneans. These data may help better circumscribe individual lineages of this artificial assemblage of monogeneans from different families of catfishes.

\section{Conflict of interest}

None

\section{Acknowledgements}

The authors thank two anonymous reviewers for their helpful suggestions, the Companhia Energética de São Paulo (CESP) for providing the facilities and logistic support for field expeditions and Célio Magalhães (Coleção de Invertebrados, Instituto Nacional de Pesquisas da Amazônia - INPA, Brasil) for lending paratypes of Cosmetocleithrum spp. Aline A. Acosta was supported by the Fundação de Amparo à Pesquisa do Estado de São Paulo - FAPESP [2012/22895-7; 2015/ 22382-8], by the Institute of Parasitology [RVO: 60077344] and the Czech Science Foundation (project \# P505/12/G112). Philippe V. Alves was supported by a postgraduate fellowship from the Conselho Nacional de Desenvolvimento Científico e Tecnológico (CNPq) and grants from the Institute of Parasitology and the Czech Science Foundation. Reinaldo J. da Silva was supported by CNPq [307808/ 2014-9] and CNPq-PROTAX [440496/2015-2/FAPESP 2016/ 50377-1].

\section{References}

[1] W.N. Eschmeyer, J.D. Fong, Species by family/subfamily, http://researcharchive. calacademy.org/research/ichthyology/catalog/SpeciesByFamily.asp (Electronic version accessed in May $\left.15^{\text {th }}, 2017\right)$.

[2] J.S. Nelson, Fishes of the World, fourth ed., John Wiley \& Sons, New York, 2006.

[3] J.S. Albert, R.E. Reis, Introduction of neotropical freshwater, in: J.S. Albert, R.E. Reis (Eds.), Historical Biogeography of Neotropical Freshwater Fishes, first ed., University of California Press, California, 2011, pp. 3-19.

[4] C.A. Mendoza-Palmero, T. Scholz, E.F. Mendoza-Franco, R. Kuchta, New species and geographical records of dactylogyrids (Monogenea) of catfish (Siluriformes) from the Peruvian Amazonia, J. Parasitol. 98 (2012) 484-497, http://dx.doi.org/ 10.1645/GE-2941.1.

[5] A. de Chambrier, T. Scholz, R. Kuchta, Taxonomic status of Woodland's enigmatic tapeworms (Cestoda: Proteocephalidea) from Amazonian catfishes: back to museum collections, Syst. Parasitol. 87 (2014) 1-19, http://dx.doi.org/10.1007/s11230013-9457-0.
[6] V.E. Thatcher, Amazon Fish Parasites, Second ed., Pensoft, Sofia, Bulgaria, 2006.

[7] S.C. Cohen, A. Kohn, South American Monogenea - list of species, hosts and geographical distribution from 1997 to 2008, Zootaxa 1924 (2008) 1-42, http://dx doi.org/10.5281/zenodo.184771.

[8] C.A. Mendoza-Palmero, I. Blasco-Costa, T. Scholz, Molecular phylogeny of Neotropical monogeneans (Platyhelminthes: Monogenea) from catfishes (Siluriformes), Parasit. Vectors 8 (2015) 164, http://dx.doi.org/10.1186/s13071015-0767-8.

[9] J.L.O. Birindelli, Phylogenetic relationships of the South American Doradoidea (Ostariophysi: Siluriformes), Neotrop. Ichthyol. 12 (2014) 451-564, http://dx.doi. org/10.1590/1982-0224-20120027.

[10] S.C. Cohen, M.C.N. Justo, A. Kohn (Eds.), South American Monogenoidea Parasites of Fishes, Amphibians and Reptiles, first ed., Fundação Oswaldo Cruz e, Conselho Nacional de Desenvolvimento Científico e Tecnológico, Rio de Janeiro, 2013.

[11] M.P. Braga, S.B.L. Araújo, W.A. Boeger, Patterns of interaction between Neotropical freshwater fishes and their gill Monogenoidea (Platyhelminthes), Parasitol. Res. 113 (2014) 481-490, http://dx.doi.org/10.1007/s00436-013-3677-8.

[12] J.W. Armbruster, Global Catfish Biodiversity, Am. Fish. Soc. Symp. 77 (2011) $15-37$.

[13] A.A. Acosta, L. Franceschini, A.C. Zago, T. Scholz, R.J. Silva, Six New species of Heteropriapulus (Monogenea: Dactylogyridae) from South American fishes with an amended diagnosis do the genus, Zootaxa 4290 (3) (2017) 459-482, http://dx.doi. org/10.11646/zootaxa.4290.3.3.

[14] D.M. Suriano, Demidospermus anus gen. nov. sp. nov. (Monogenea: Ancyrocephalinae) parasite branquial de Loricaria (L.) anus Valenciennes, 1840 (Pisces: Loricariidae) de la Laguna de Chascomus - Provincia de Buenos Aires Republica Argentina, Neotropica 29 (1983) 111-119.

[15] D.C. Kritsky, P.A. Gutiérrez, Neotropical Monogenoidea. 34. Species of Demidospermus (Dactylogyridae, Ancyrocephalinae) from the gills of pimelodids (Teleostei, Siluriformes) in Argentina, Proc. Helminthol. Soc. Wash. 65 (1998) (1998) 147-159.

[16] L. Franceschini, A.C. Zago, M.I. Müller, C.J. Francisco, R.M. Takemoto, R.J. Silva, Morphology and molecular characterization of Demidospermus spirophallus n. sp., $D$. prolixus n. sp. (Monogenea: Dactylogyridae) and a redescription of $D$. anus in siluriform catfish from Brazil, J. Helminthol. (2017) [published online] (2017) http://dx.doi.org/10.1017/S0022149X17000256.

[17] D.C. Kritsky, V.E. Thatcher, W.A. Boeger, Neotropical Monogenea. 8. Revision of Urocleidoides (Dactylogyridae, Ancyrocephalinae), Proc. Helminthol. Soc. Wash. 53 (1986) 1-37.

[18] J.D. Mizelle, A.R. Klucka, Studies on monogenetic trematodes. XIV. Dactylogyridae from Wisconsin fishes, Am. Midl. Nat. 49 (1953) (1953) 720-733.

[19] D.C. Kritsky, W.A. Boeger, V.E. Thatcher, Neotropical Monogenea. 7. Parasites of pirarucu, Arapaima gigas (Cuvier), with descriptions of two new species and redescription of Dawestrema cycloancistrium Price and Nowlin, 1967 (Dactylogyridae: Ancyrochepalinae), Proc. Helminthol. Soc. Wash. 98 (1985) 321-331.

[20] J.D. Mizelle, D.C. Kritsky, Studies on monogenetic trematodes. XXX. Five new species of Gyrodactylus from the Pacific tomcod, Microgadus proximus (Girard), J. Parasitol. 53 (1967) 263-269.

[21] D.C. Kritsky, J.D. Mizelle, Studies on monogenetic trematodes. XXXV. Some new and previously described North American species of Gyrodactylus, Am. Midl. Nat. 79 (1968) 205-215.

[22] J.D. Mizelle, New species of trematodes from the gills of Illinois fishes, Am. Midl. Nat. 17 (1936) (1936) 785-806.

[23] F. Pleijel, U. Jondelius, E. Norlinder, A. Nygren, B. Oxelman, C. Schander, P. Sundberg, M. Thollesson, Phylogenies without roots? A plea for the use of vouchers in molecular phylogenetic studies, Mol. Phylogenet. Evol. 48 (2008) 369-371, http://dx.doi.org/10.1016/j.ympev.2008.03.024.

[24] R. Ergens, The suitability of ammonium picrate-glycerin in preparing slides of lower Monogenoidea, Folia Parasitol. 16 (1969) 320.

[25] A.E. Lockyer, P.D. Olson, D.T.J. Littlewood, Utility of complete large and small subunit rRNA genes in resolving the phylogeny of the Neodermata (Platyhelminthes): implications and a review of the cercomer theory, Biol. J. Linn. Soc. 78 (2003) 155-171, http://dx doi.org/10.1046/j.1095-8312.2003.00141.x.

[26] E.C. Werle, C. Schneider, M. Renner, M. Völker, W. Fiehn, Convenient single-step, one tube purification of PCR products for direct sequencing, Nucleic Acids Res. 22 (1994) 4354-4355.

[27] P.D. Olson, T.H. Cribb, V.V. Tkach, R.A. Bray, D.T.J. Littlewood, Phylogeny and classification of the Digenea (Platyhelminthes: Trematoda), Int. J. Parasitol. 33 (2003) 733-755, http://dx.doi.org/10.1016/S0020-7519(03)00049-3.

[28] D.T.J. Littlewood, M. Curini-Galletti, E.A. Herniou, The interrelationships of Proseriata (Platyhelminthes: Seriata) tested with molecules and morphology, Mol Phylogenet. Evol. 16 (2000) 449-466, http://dx.doi.org/10.1006/mpev.2000. 0802.

[29] M. Kearse, R. Moir, A. Wilson, S. Stones-Havas, M. Cheung, S. Sturrock, S. Buxton, A. Cooper, S. Markowitz, C. Duran, T. Thierer, B. Ashton, P. Mentjies, A. Drummond, Geneious Basic: an integrated and extendable desktop software platform for the organization and analysis of sequence data, Bioinformatics 28 (2012) 1647-1649, http://dx.doi.org/10.1093/bioinformatics/bts199.

[30] I. Sela, H. Ashkenazy, K. Katoh, T. Pupko, GUIDANCE2: accurate detection of unreliable alignment regions accounting for the uncertainty of multiple parameters, Nucleic Acids Res. 43 (2015) W7-W14, http://dx.doi.org/10.1093/nar/gkv318.

[31] O. Penn, E. Privman, G. Landan, D. Graur, T. Pupko, An alignment confidence score capturing robustness to guide-tree uncertainty, Mol. Biol. Evol. 27 (2010) 1759-1767, http://dx.doi.org/10.1093/molbev/msq066.

[32] S. Guindon, O. Gascuel, A simple, fast, and accurate algorithm to estimate large phylogenies by maximum likelihood, Syst. Biol. 52 (2003) 696-704. 
[33] D. Darriba, G.L. Taboada, R. Doallo, D. Posada, jModelTest 2: more models, new heuristics and parallel computing, Nat. Methods 9 (2012) 772, http://dx.doi.org/ 10.1038/nmeth.2109.

[34] F. Ronquist, M. Teslenko, P. Van Der Mark, D.L. Ayres, A. Darling, S. Höhna, B. Larget, L. Liu, M.A. Suchard, J.P. Huelsenbeck, MrBayes 3.2: efficient Bayesian phylogenetic inference and model choice across a large model space, Syst. Biol. 61 (2012) 539-542, http://dx.doi.org/10.1093/sysbio/sys029.

[35] M.A. Miller, W. Pfeiffer, T. Schwartz, Creating the CIPRES Science Gateway for inference of large phylogenetic trees, SC10 Workshop on Gateway Computing Environments (GCE10), New Orleans, November 14 (2010) 1-8, http://dx.doi.org/ $10.1145 / 2016741.2016785$

[36] K. Tamura, D. Peterson, N. Peterson, G. Stecher, M. Nei, S. Kumar, MEGA5: molecular evolutionary genetics analysis using maximum likelihood, evolutionary distance, and maximum parsimony methods, Mol. Biol. Evol. 28 (2001) 2731-2739, http://dx.doi.org/10.1093/molbev/msr121.

[37] E.F. Mendoza-Franco, C.A. Mendoza-Palmero, T. Scholz, New species of Ameloblastella Kritsky, Mendoza-Franco \& Scholz, 2000 and Cosmetocleithrum Kritsky, Thatcher \& Boeger, 1986 (Monogenea: Dactylogyridae) infecting the gills of catfishes (Siluriformes) from the Peruvian Amazonia, Syst. Parasitol. 93 (2016) 847-862, http://dx.doi.org/10.1007/s11230-016-9671-7.

[38] C.A. Mendoza-Palmero, I. Blasco-Costa, D. Hernández-Mena, G. Pérez-Ponce de León, Parasciadicleithrum octofasciatum n. gen., n. sp. (Monogenoidea:
Dactylogyridae) parasite of Rocio octofasciata (Regan) (Cichlidae: Perciformes) from Mexico characterised by morphological and molecular evidence, Parasitol. Int. 66 (2017) 152-162, http://dx.doi.org/10.1016/j.parint2017.01.006.

[39] A.P. Ferrari-Hoeinghaus, S. Bellay, R.M. Takemoto, G.C. Pavanelli, A new species of Demidospermus Suriano, 1983 (Monogenea, Dactylogyridae) parasitic on Loricariichthys platymetopon Isbrücker et Nijssen (Loricariidae, Siluriformes) from the Upper Paraná River floodplain, Brazil, Acta Parasitol. 55 (2010) 16-19, http:/ dx.doi.org/10.2478/s11686-010-0007-5.

[40] D.C. Kritsky, F. Stephens, Haliotrema abaddon n. sp. (Monogenoidea:Dactylogyridae) from the gills of wild and maricultured West Australian dhufish Glaucosoma hebraicum (Teleostei: Glaucosomatidae), in Australia, J. Parasitol. 87 (2001) 749-754, http://dx.doi.org/10.1645/0022 3395(2001)087[0749:HANSMD]2.0.CO;2.

[41] J.G. Lundberg, L.G. Marshall, J. Guerrero, B. Horton, M.C.S.L. Malabarba, F. Wesselingh, The stage for Neotropical fish diversification: A history of tropical south American rivers, in: L.R. Malabarba, R.E. Reis, R.P. Vari, Z.M.S. Lucena, C.A.S. Lucena (Eds.), Phylogeny and Classification of Neotropical Fishes, Edipucrs, Porto Alegre, 1998, pp. 13-48.

[42] A. Šimková, I. Matějusová, C.O. Cunningham, A molecular phylogeny of the Dactylogyridae sensu Kritsky \& Boeger (1989) based on the D1-D3 domains of large subunit rDNA, Parasitology 133 (2006) 43-53, http://dx.doi.org/10.1017/ S0031182006009942. 